\title{
Zmiana parametrów reologicznych zaczynu lateksowego pod wpływem dodatku mikrosfery
}

\section{Change of rheological parameters of latex cement slurry by microsphere material addition}

\author{
Marcin Kremieniewski \\ Instytut Nafty i Gazu - Państwowy Instytut Badawczy
}

\begin{abstract}
STRESZCZENIE: Receptury zaczynów cementowych o niskiej gęstości tzw. lekkich są najczęściej używane do uszczelniania kolumn rur okładzinowych posadowionych w słabozwięzłych formacjach geologicznych i warstwach sypkich. Zastosowanie takiej receptury pozwala obniżyć wartość ciśnienia hydrostatycznego, dzięki czemu zaczyn nie powoduje rozszczelinowania delikatnej struktury ściany otworu. Obniżenie gęstości zaczynu jest możliwe poprzez wprowadzenie lekkich dodatków wypełniających. Najczęściej stosowanym wypełniaczem lekkim są mikrosfery. Jednak zastosowanie tego dodatku powoduje zmianę parametrów reologicznych, co nie pozostaje bez wpływu na przetłaczalność projektowanego zaczynu. W celu uzyskania odpowiedniego wypełnienia zaczynem cementowym przestrzeni pierścieniowej lub pozarurowej należy w taki sposób projektować jego parametry reologiczne, aby uzyskać odpowiednie wyparcie płuczki z otworu oraz jak najlepsze wypełnienie skawernowanej ściany otworu. W tym celu niezbędne jest obniżenie wartości parametrów reologicznych zaczynu. Jednakże niskie wartości lepkości plastycznej i granicy płynięcia mogą skutkować nadmiernym frakcjonowaniem zaczynu zawierającego dodatek mikrosfer, wskutek czego zarówno zaczyn cementowy i powstały z niego w otworze płaszcz cementowy nie będzie wykazywał odpowiedniej jednorodności. W związku z powyższym, aby odpowiednio zaprojektować recepturę zaczynu lekkiego, którego gęstość regulowana jest przez wprowadzenie dodatku mikrosfer należy wcześniej określić zmianę wartości parametrów reologicznych pod wpływem dodatku mikrosfer, co zostało omówione w niniejszym artykule. W publikacji przedstawione zostały wyniki prac dotyczące zmiany parametrów reologicznych zaczynu lateksowego pod wpływem wzrastającej ilości mikrosfer. Zaprojektowano 6 zaczynów, pośród których 3 receptury stanowiły punkty odniesienia, a kolejne trzy to zaczyny modyfikowane 40\%-ową ilością mikrosfer. Zaczyny bazowe zawierały 5\% mikrosfery w stosunku do masy cementu, a nowo opracowane receptury na podstawie których badano wpływ dodatku mikrosfer zawierały $40 \%$ mikrosfer glinokrzemianowych. Projektowane zaczyny przeznaczone były dla warunków otworowych o zakresie temperatur od $30^{\circ} \mathrm{C}$ do $70^{\circ} \mathrm{C}$ i odpowiadających im ciśnień złożowych w zakresie od $5 \mathrm{MPa}$ do $20 \mathrm{MPa}$. W trakcie realizowania prac badawczych skoncentrowano się na wpływie dodatku mikrosfer na parametry reologiczne zaczynu lekkiego ze względu na to, że dodatek ten jest najczęściej stosowanym materiałem wypełniających, a uzyskane wyniki prac mogą być pomocne podczas projektowania kolejnych nowych receptur zaczynów o obniżonej gęstości.
\end{abstract}

Słowa kluczowe: zaczyn cementowy, zaczyn lekki, zaczyn lateksowy, mikrosfery, parametry reologiczne.

\begin{abstract}
Lightweight cement slurry are most often used to seal columns of casing pipes set in weakly compact geological formations and loose layers. By using this cement slurry the hydrostatic pressure can be lowered, so that the slurry does not fracture the delicate structure of the borehole wall. Lowering the slurry density is possible by introducing light fill-up additives. Microspheres are the most commonly used light fillers. However, the use of this additive causes a change in rheological parameters, which has an impact on the transferability of the designed cement slurry. In order to obtain adequate cement slurry filling of the annular space, its rheological parameters should be designed in such a way so as to obtain adequate displacement of the mud from the hole and the best possible filling of the caved wall of the borehole. To this end, it is necessary to lower the rheological parameters of the cement slurry. However, low values of the plastic viscosity and the flow limit may result in excessive fractionation of the slurry containing the addition of microspheres, as a result of which both the cement slurry and the cement sheath resulting from it will not show adequate homogeneity. Therefore, in order to properly design the lightweight slurry recipe, whose density is regulated by the addition of microspheres, one must first determine the change in the value of rheological parameters under the influence of the addition of microspheres, which was discussed in this article. The publication presents the results of works on the change of rheological parameters of latex cement slurry under the influence of increasing number of microspheres. Six slurries were designed, of which three recipes were reference points, and the next three were modified with $40 \%$ of the microspheres. The base cement slurries contained $5 \%$ microspheres in relation to the mass of cement, and the newly developed recipes on the basis of which the effect of the addition of microspheres was investigated
\end{abstract}

Autor do korespondencji: M. Kremieniewski, e-mail: marcin.kremieniewski@inig.pl

Artykuł nadesłano do Redakcji: 30.09.2019 r. Zatwierdzono do druku: 30.12.2019 r. 
contained $40 \%$ aluminosilicate microspheres. The designed slurries were intended for well conditions with a temperature range from $30^{\circ} \mathrm{C}$ to $70^{\circ} \mathrm{C}$ and corresponding reservoir pressures in the range from $5 \mathrm{MPa}$ to $20 \mathrm{MPa}$. During the research, the focus was on the impact of the addition of microspheres on the rheological parameters of lightweight cement slurry, because this addition is the most commonly used filling material, and the results obtained can be helpful when designing, new, reduced density cement slurry recipes.

Key words: cement slurry, lightweight slurry, latex slurry, microspheres, rheological parameter.

\section{Wprowadzenie}

Zaczyn o obniżonej gęstości stosuje się do uszczelniania stref niskiego ciśnienia złożowego, cementowania kolumn rur okładzinowych w profilu skał słabozwięzłych chłonnych lub gdy zachodzi konieczność podniesienia cementu w przestrzeni pozarurowej na dużą wysokość (Raczkowski et al., 1978; Nelson et al 1990). Zmniejszenie gęstości zaczynu pozwala zredukować wartość ciśnienia hydrostatycznego podczas cementowania, dzięki czemu możliwe jest obniżenie gradientu szczelinowania (Rzepka et al., 2012; Kremieniewski M., 2019b,). Do obniżenia gęstości zaczynu, który określany jest mianem zaczynu „lekkiego” w branży naftowej najczęściej stosuje się dodatek mikrosfer. Mikrosfery stosowane w technologii zaczynów cementowych to sferyczne cząsteczki wypełnione gazem (rys. 1). Wartość gęstości mikrosfer zawiera się w przedziale od 40 do $60 \mathrm{~kg} / \mathrm{m}^{3}$, dzięki czemu możliwe jest obniżenie gęstości projektowanego zaczynu cementowego nawet do wartości wynoszącej $900 \mathrm{~kg} / \mathrm{m}^{3}$, co przedstawiono na rysunku 2 (dla porównania zaczyn o normalnej gęstości sporządzony na bazie cementu wiertniczego klasy G posiada gęstość około $1900 \mathrm{~kg} / \mathrm{m}^{3}$ ) (Stryczek et al., 2005; Kremieniewski i Stryczek, 2019).

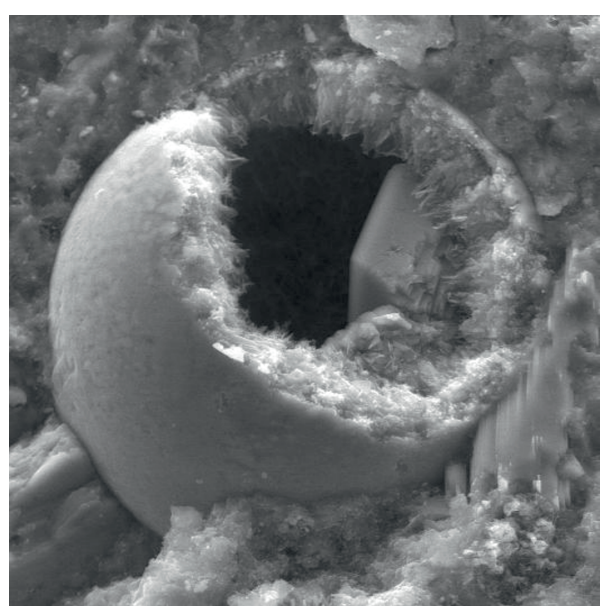

Rys. 1. Cząsteczka mikrosfery obecna w stwardniałym zaczynie cementowym na zdjęciu z mikroskopu skaningowego

Fig. 1. The microsphere molecule present in the hardened cement slurry in the photo from the scanning microscope

Należy zaznaczyć, że zaczyny z dodatkiem mikrosfer charakteryzują się niższymi niż standardowe zaczyny wartościami

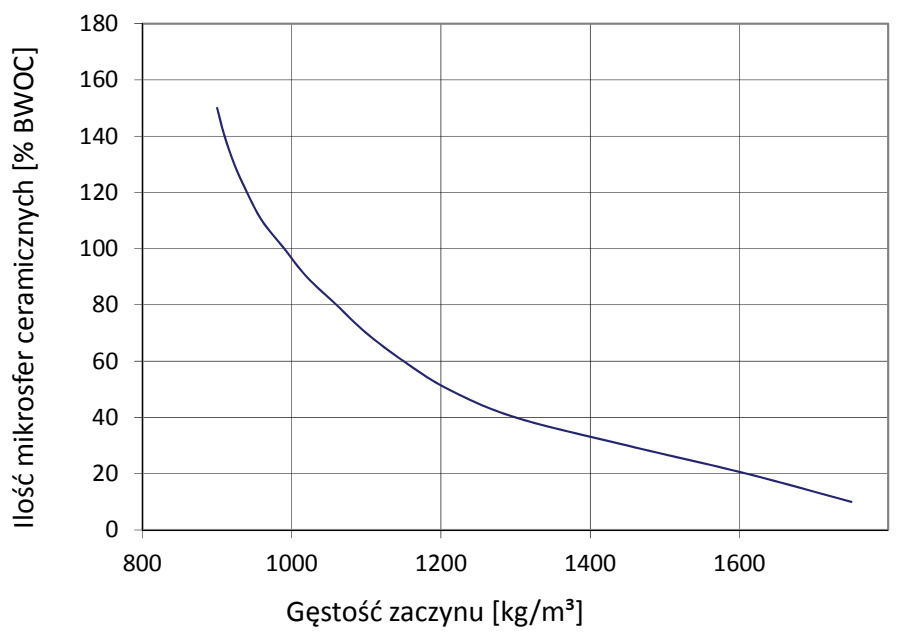

Rys. 2. Zależność gęstości zaczynu od ilości mikrosfer [bwoc]

Fig. 2. Dependence of the density of the slurry on the amount of microspheres [bwoc]

parametrów mechanicznych (wytrzymałości na ściskanie, przyczepności do rur stalowych i do formacji skalnej, wytrzymałości na zginanie) (Kudowski, 2010; Falode et al., 2013; Kremieniewski, 2018a). Dodatkowo zaczyny z dodatkiem mikrosfer (ze względu na wzrost porowatości efektywnej) posiadają wyższą wartość współczynnika przepuszczalności, co jest niekorzystne pod kątem uzyskania odpowiedniej szczelności projektowanego zaczynu (Kremieniewski i Rzepka, 2016). Jednak takie niekorzystne wartości parametrów są modyfikowane przez użycie środków, dodatków i domieszek, których obecność pozwala doszczelnić matrycę, a tym samym obniżyć przepuszczalność dla gazu oraz poprawić uzyskiwane wartości parametrów mechanicznych.

Podczas projektowania i realizacji prac związanych z uszczelnieniem otworów wiertniczych bardzo ważne są parametry reologiczne zaczynu cementowego. Aby zapewnić maksymalną efektywność uszczelniania kolumn rur okładzinowych należy dobierać parametry reologiczne w taki sposób, aby dostosować je do warunków złożowych uszczelnianych skał, geometrii otworu wiertniczego oraz systemu cyrkulacyjnego (Rzepka i Stryczek 2008; Stryczek et al., 2009; Jordan et al., 2018).

Należy w tym miejscu wspomnieć, że najmocniejszy wpływ dodatku mikrosfer w zaczynie cementowym obserwuje się właśnie podczas analizy wartości parametrów reologicznych. Na podstawie prowadzonych badań i analizy 
procesów cementowania przestrzeni pierścieniowej zaobserwowano, iż najwyższą skuteczność uszczelniania uzyskuje się tłocząc zaczyn przy przepływie turbulentnym (Kremieniewski, 2019a). W celu utrzymania takiego charakteru przepływu należy zwiększać prędkość przepływu zaczynu proporcjonalnie do wzrostu jego lepkości plastycznej. Jednak większe prędkości przepływu są możliwe do uzyskania poprzez zwiększenie wydajności tłoczenia, a to powoduje wzrost oporów przepływu i końcowego ciśnienia cementowania. Opór przepływu wzrasta znacznie szybciej niż wzrost lepkości, co przedstawiono na rysunku 3 i takie zachowanie zaczynu powoduje zagrożenie szczelinowaniem skał słabozwięzłych (Półchłopek et al., 1993; Kremieniewski 2018b), na co szczególnie podatny jest profil, który uszczelnia się zaczynem o obniżonej gęstości. W takim przypadku rozsądne jest użycie zaczynów o możliwie niskiej lepkości plastycznej. Jednakże podczas projektowania zaczynów lekkich utrudnione jest obniżenie wartości lepkości plastycznej w taki sposób, aby nie nastąpiła segregacja składników zaczynu cementowego, co w dużej mierze decyduje o stabilności sedymentacyjnej zaczynu cementowego.

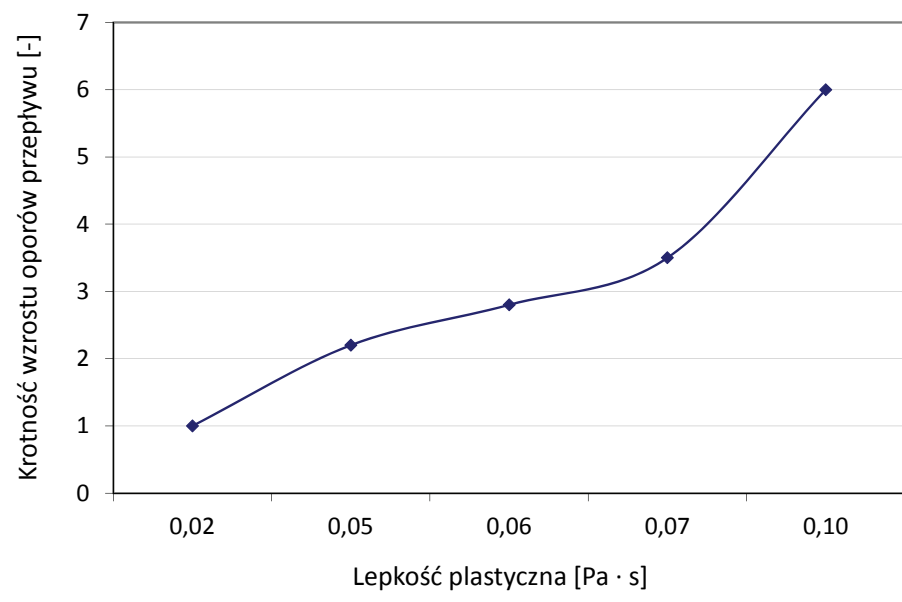

Rys. 3. Wzrost oporów przepływu w zależności od lepkości plastycznej zaczynu cementowego

Fig. 3. Increase of flow resistance depending on the plastic viscosity of cement slurry

Ponieważ lepkość plastyczna zaczynu powinna być zawsze większa od lepkości plastycznej płuczki, to przed przystąpieniem do zabiegu cementowania należy maksymalnie obniżyć lepkość plastyczną płuczki (Stryczek et al., 2014). Ważnym parametrem jest również wskaźnik konsystencji $k\left[\mathrm{~N} \cdot \mathrm{s}^{\mathrm{n}} / \mathrm{m}^{2}\right]$, który jest odpowiednikiem lepkości plastycznej dla cieczy pseudoplastycznej. Podczas prowadzenia zabiegu cementowania (zwłaszcza przy przepływie turbulentnym) korzystne jest stosowanie zaczynów cementowych o niskich wartościach współczynnika konsystencji $k$. Wzrost wartości współczynnika $k$ powoduje nieznaczne obniżanie zdolności wypierania płuczki przez zaczyn (Wiśniowski et al., 2007; Stryczek et al., 2014).

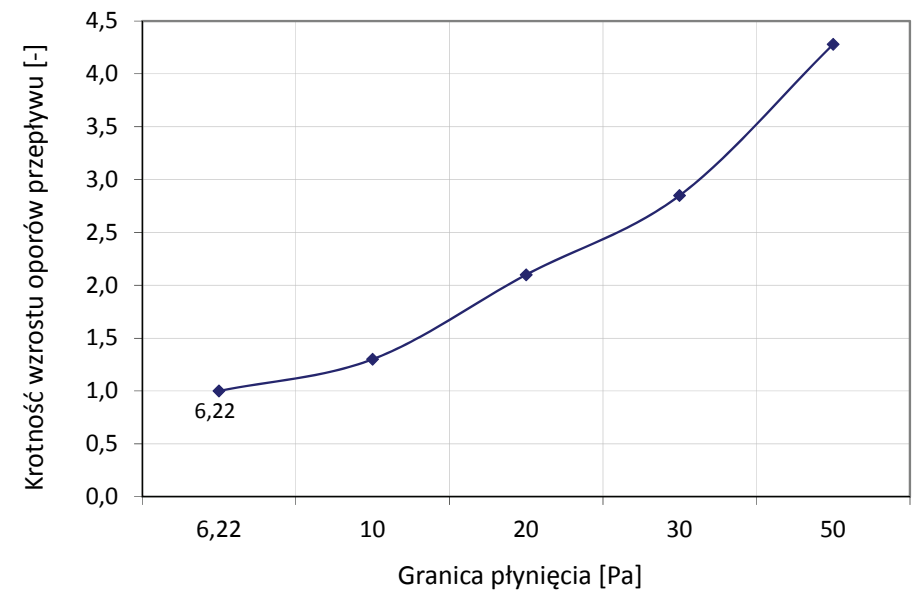

Rys. 4. Wzrost oporów przepływu w zależności od granicy płynięcia zaczynu cementowego

Fig. 4. Increase of flow resistance depending on the flow limit of cement slurry

Kolejnym istotnym parametrem reologicznym zaczynu cementowego jest jego granica płynięcia. Jej wartość wpływa na możliwość utrzymania lekkich frakcji w całej objętości zaczynu (Kremieniewski, 2017a). Jednak wzrost wartości granicy płynięcia w zaczynie cementowym powoduje niekorzystny wzrost oporów przepływu (rys. 4), a to z kolei może doprowadzić do wystąpienia szczelinowania lub nawet ucieczki zaczynu podczas zabiegu cementowania. Analizując wyniki prowadzonych prac badawczych oraz dane literaturowe (Herianto i Fathaddin, 2005; Półchłopek et al., 1993; Kremieniewski et al., 2017) można stwierdzić, że najbardziej korzystne jest utrzymanie granicy płynięcia zaczynu cementowego $\mathrm{w}$ odpowiednim zakresie dostosowanym do konkretnych warunków otworowych. Pozwala to na prawidłowe wyparcie płuczki wiertniczej i wymagane uszczelnienie przestrzeni pierścieniowej. Zarówno lepkość plastyczną, jak i granicę płynięcia można kształtować w szerokim zakresie poprzez regulację na przykład: koncentracji objętościowej cementu, która zależy od współczynnika wodno-cementowego, rodzaju zastosowanego cementu, ilości i rodzaju dodatków drobnoziarnistych, domieszek superplastyfikatorów, domieszek zwiększających lepkość oraz dodatków mineralnych (Bayu et al., 2010; Pneg i Jacobsen, 2013; Kremieniewski 2017b, 2019c).

Zaczyny lekkie z dodatkiem mikrosfer charakteryzują się również określonym stosunkiem wodno-cementowym. Dla danej ilości mikrosfer wymagane jest zastosowanie określonej ilości wody. Zależność ta ma charakterystykę liniową i przedstawiona jest na wykresie (rys. 5). W związku z powyższym w celu pozostawienia optymalnych wartości omawianych parametrów reologicznych zaczynu z dodatkiem mikrosfer należy zastosować dodatkową porcję wody lub użyć domieszkę plastyfikatora (Półchłopek et al., 1993; Bensted, 2004). 


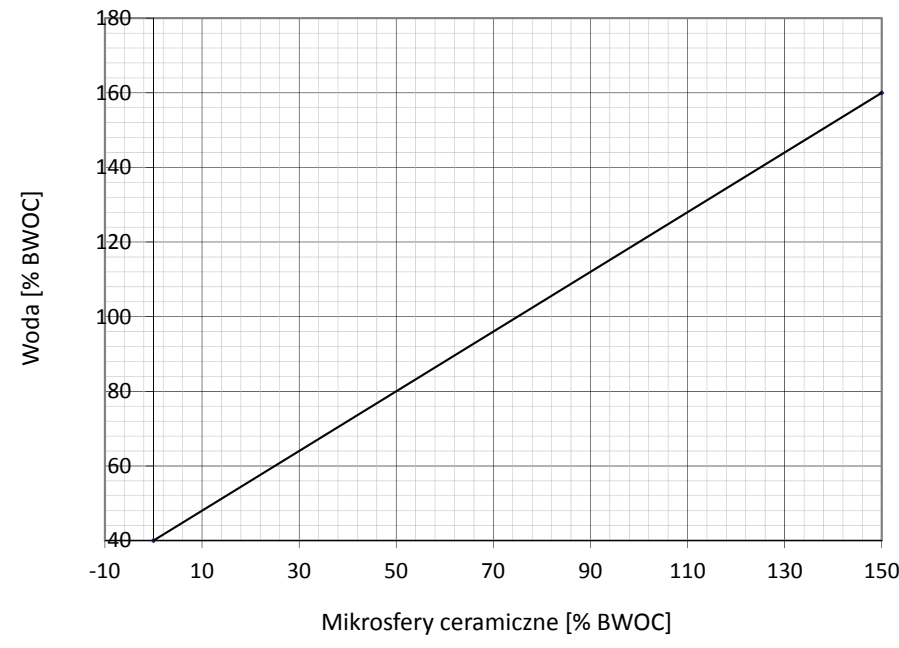

Rys. 5. Zawartość wody w zaczynach z dodatkiem mikrosfer

Fig. 5. Water content in slurries with the addition of microspheres

W dalszej części niniejszej publikacji omówione zostały wyniki prac badawczych dotyczących zmiany parametrów reologicznych zaczynu lateksowego pod wpływem dodatku mikrosfery. Jest to bardzo ważne zagadnienie z punktu widzenia efektywności uszczelnienia przestrzeni pierścieniowej i pozarurowej za pomocą zaczynu o znacznej ilości lekkiego wypełniacza, jakim jest dodatek mikrosfer. Prawidłowo dobrane parametry reologiczne w tego rodzaju zaczynach umożliwiają zatłoczenie zaczynu w taki sposób, aby uzyskać maksymalne wypełnienie kawern i usunąć pozostałości płuczki z otworu, a jednocześnie nie powodować nadmiernego wzrostu ciśnienia szczelinowania przez zaczyn na skutek niekorzystnych wartości parametrów reologicznych.

\section{Przebieg prac badawczych}

Badania zmian parametrów reologicznych zaczynu lateksowego pod wpływem dodatku mikrosfery zostały zrealizowane w Laboratorium Zaczynów Uszczelniających INiG - PIB w oparciu o normy: PN-85/G-02320 Cementy $i$ zaczyny cementowe do cementowania w otworach wiertniczych; PN-EN 10426-2 Przemyst naftowy i gazowniczy. Cementy i materiały do cementowania otworów. Część 2: Badania cementów wiertniczych oraz API SPEC 10 Specification for materials and testing for well cements.

Celem cyklu badawczego, który został omówiony w niniejszej publikacji, było wykazanie wpływu dodatku mikrosfer glinokrzemianowych na zmianę parametrów reologicznych projektowanego zaczynu cementowego. Jak już wspomniano, receptury zaczynów lekkich przysparzają trudności w odpowiednim doborze parametrów technologicznych ze względu na konieczność uzyskania wymaganych własności reologicznych przy jednoczesnym utrzymaniu odpowiedniej stabilności sedymentacyjnej. Związane jest to $\mathrm{z}$ faktem, że w celu uzyskania wymaganej przetłaczalności przy niskim wydatku tłoczenia należy utrzymywać parametry reologiczne w dolnym zakresie, natomiast w celu przeciwdziałania frakcjonowania zaczynu wymagane jest zwiększenie wartości granicy płynięcia i lepkości plastycznej. Podczas projektowania receptur zaczynów lekkich głównym czynnikiem decydującym o jakości zaczynu jest właśnie obecność wypełniaczy lekkich.

W trakcie realizacji prac na podstawie których określono wpływ dodatku mikrosfer na parametry reologiczne, badaniom poddano w sumie 6 składów zaczynów. Jako punkt odniesienia wykonano trzy receptury kontrolne. Głównymi zaczynami poddanymi badaniom były 3 składy zawierające $40 \%\left(\mathrm{BWOC}^{1}\right)$ mikrosfer glinokrzemianowych. W celu określenia wpływu dodatku mikrosfer, badania parametrów reologicznych wykonane zostały dla trzech zaczynów przeznaczonych do zróżnicowanych warunków geologiczno złożowych (temperatura $30^{\circ} \mathrm{C}$ i ciśnienie $5 \mathrm{MPa}$; temperatura $50^{\circ} \mathrm{C}$ i ciśnienie $12 \mathrm{MPa}$; oraz temperatura $70^{\circ} \mathrm{C}$ i ciśnienie $20 \mathrm{MPa}$ ). Zaczyny kontrolne również zawierały niewielką 5\%-ową ilość mikrosfer. Takie działanie w próbce kontrolnej miało ma celu porównanie zaczynu badanego ( $40 \%$ mikrosfer) z zaczynem o minimalnej ilości mikrosfer. Obecność tak niewielkiej ilości mikrosfer nie wykazuje znacznego wpływu na parametry zaczynu, ale jednocześnie skład takiego zaczynu jest bardziej zbliżony do receptury zaczynu lekkiego poprzez na przykład obecność domieszki bentonitu, którego nie stosuje się w zaczynie o normalnej gęstości. Podczas projektowania zaczynów cementowych materiałem wiążącym był cement wiertniczy G HSR. Głównym kryterium takiego wyboru było stosowanie tego rodzaju spoiwa w warunkach przemysłowych. W płytkich otworach, charakteryzujących się niskimi temperaturami i ciśnieniami dennymi stosowany jest cement portlandzki klasy CEM I 42,5R. Jednak podczas realizacji cyklu badawczego we wszystkich recepturach zastosowano cement G HSR w celu wyeliminowania rozbieżności wyników związanych z zastosowaniem różnych rodzajów spoiw.

Receptury kontrolne zawierały w składzie domieszkę bentonitu $1,2 \% \mathrm{w}$ stosunku do ilości wody zarobowej oraz mikrosferę glinokrzemianową w ilości 5\%. Odmierzoną ilość bentonitu zmieszano $\mathrm{z}$ wodą zarobową przed zastosowaniem pozostałych składników zaczynu. Ze względu, iż zalecane jest dawkowanie bentonitu do wody zarobowej i mieszanie go $30 \mathrm{mi}-$ nut, przyjęto taką metodyką sporządzania zaczynu. Zaczyny charakteryzowały się współczynnikiem wodno-cementowym równym 0,8 . Były one sporządzone na wodzie wodociągowej

\footnotetext{
${ }^{1}$ BWOC (ang. by weight of cement) - w stosunku do masy cemen-
} tu w zaczynie. 
Tabela 1. Receptury zaczynów cementowych dla warunków otworowych

Table 1. Cement slurries formulations for borehole conditions

\begin{tabular}{|c|c|c|c|c|c|c|c|c|c|c|c|c|}
\hline$\dot{\mathbf{\lambda}}$ & 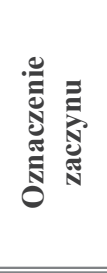 & 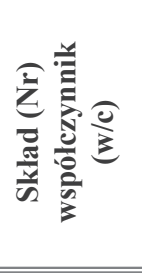 & 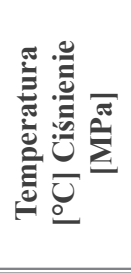 & ڤ્) & 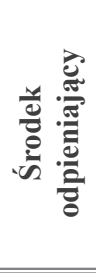 & 离 & 资 & 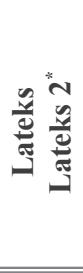 & 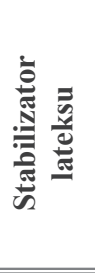 & 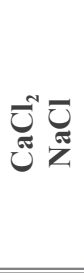 & 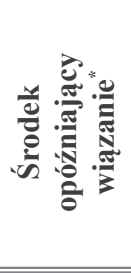 & 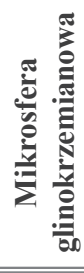 \\
\hline 1. & $\begin{array}{c}1 \\
\text { MS } 5\end{array}$ & $\begin{array}{c}\mathrm{Nr} 1 \\
\text { w/c } 0,8\end{array}$ & \multirow{2}{*}{$\begin{array}{c}30^{\circ} \mathrm{C} \\
5 \mathrm{MPa}\end{array}$} & 1,2 & 0,5 & 0,5 & 0,1 & $0,5^{*}$ & - & $20,0^{*}$ & - & 5,0 \\
\hline 2. & $\begin{array}{c}2 \\
\text { MS } 40\end{array}$ & $\begin{array}{c}\mathrm{Nr} 2 \\
\mathrm{w} / \mathrm{c}=0,9\end{array}$ & & 1,5 & 0,5 & 0,4 & 0,3 & 10,0 & 1,0 & 3,0 & - & 40,0 \\
\hline 3. & $\begin{array}{c}3 \\
\text { MS } 5\end{array}$ & $\begin{array}{c}\mathrm{Nr} 3 \\
\mathrm{w} / \mathrm{c}=0,8\end{array}$ & \multirow{2}{*}{$\begin{array}{c}50^{\circ} \mathrm{C} \\
12 \mathrm{MPa}\end{array}$} & 1,2 & 0,3 & 0,6 & 0,2 & $0,5^{*}$ & - & $20,0^{*}$ & - & 5,0 \\
\hline 4. & $\begin{array}{c}4 \\
\text { MS } 40\end{array}$ & $\begin{array}{c}\mathrm{Nr} 4 \\
\mathrm{w} / \mathrm{c}=0,9\end{array}$ & & 1,5 & 0,5 & 0,4 & 0,3 & 10,0 & 1,0 & 2,0 & - & 40,0 \\
\hline 5. & $\begin{array}{c}5 \\
\text { MS } 5\end{array}$ & $\begin{array}{c}\mathrm{Nr} 5 \\
\mathrm{w} / \mathrm{c}=0,8\end{array}$ & \multirow{2}{*}{$\begin{array}{c}70^{\circ} \mathrm{C} \\
20 \mathrm{MPa}\end{array}$} & 1,0 & 0,5 & 0,5 & 0,1 & $0,5^{*}$ & - & $20,0^{*}$ & $0,4^{*}$ & 5,0 \\
\hline 6. & $\begin{array}{c}6 \\
\text { MS } 40\end{array}$ & $\begin{array}{c}\mathrm{Nr} 6 \\
\mathrm{w} / \mathrm{c}=0,9\end{array}$ & & 1,5 & 0,5 & 0,4 & 0,3 & 10,0 & 1,0 & - & - & 40,0 \\
\hline
\end{tabular}

Spoiwo wiążące: cement G HSR $=100 \%$

Bentonit dozowano w stosunku do ilości wody zarobowej (BWOW), pozostałe składniki w stosunku do masy cementu (BWOC)

${ }^{*}$ Inny rodzaj lateksu, opóźniacza oraz chlorku

o zasoleniu $20 \% \mathrm{NaCl}$ oraz zawierały $0,5 \%$ lateksu sypkiego. Środki takie jak: środek odpieniający, antyfiltracyjny, upłynniający, przyspieszający i opóźniający czas wiązania zastosowano w ilościach podanych w tabeli 1 . Natomiast zaczyny zawierające 40\% (BWOC) mikrosfery glinokrzemianowej zawierały w składzie 1,5\% (BWOW) bentonitu oraz 10\% (BWOC) lateksu, a współczynnik wodno-cementowy dla wszystkich receptur wynosił 0,9. Pozostałe środki zastosowano w ilościach podanych w tabeli 1.

Na podstawie przyjętych kryteriów oraz proporcji mieszanin sporządzone zostały trzy receptury kontrolne oraz opracowano trzy zaczyny zmodyfikowane, dzięki czemu możliwe było określenie zmiany parametrów reologicznych zaczynu lateksowego pod wpływem dodatku mikrosfery. Szczegółowe ilości poszczególnych składników zestawiono w tabeli 1.

Analizując wstępne wyniki badań parametrów technologicznych zaczynów stwierdzono prawidłową zależność objawiającą się znacznym obniżeniem gęstości wszystkich receptur zaczynów po wprowadzeniu dodatkowej porcji mikrosfer glinokrzemianowych. Gęstość zaczynów bazowych, zawierających 5\% mikrosfer wynosiła $1600 \mathrm{~kg} / \mathrm{m}^{3}$, natomiast zastosowanie 40\%-owej koncentracji dodatku mikrosfer skutkowało uzyskaniem gęstości wynoszącej $1220 \mathrm{~kg} / \mathrm{m}^{3}$, co przedstawiono na rysunku 5. Zaobserwowano również, że mimo wzrostu ilości mikrosfer w stosunku do zaczynów bazowych, wartość filtracji zaczynów zawierających dodatkową porcję mikrosfer ulegała obniżeniu w porównaniu do receptur kontrolnych. W zaczynie dla warunków otworowych o temperaturze $30^{\circ} \mathrm{C}$ wartość filtracji zmniejszyła się o $107 \mathrm{~cm}^{3} / 30 \mathrm{~min}$ w porównaniu do zaczynu kontrolnego, dla temperatury $50^{\circ} \mathrm{C}$ uzyskano o $32 \mathrm{~cm}^{3} / 30 \mathrm{~min}$ niższą wartość filtracji niż w odpowiadającym mu zaczynie kontrolnym. $Z$ kolei w zaczynie przeznaczonym do uszczelniania kolumn rur w otworach o temperaturze $70^{\circ} \mathrm{C}$ filtracja była niższa o $206 \mathrm{~cm}^{3} / 30$ min niż w zaczynie kontrolnym. Wyniki zestawiono na rysunku 6 . Tak mocne obniżenie wartości filtracji w zaczynach może być efektem obecności 10\%-owej koncentracji płynnego lateksu.

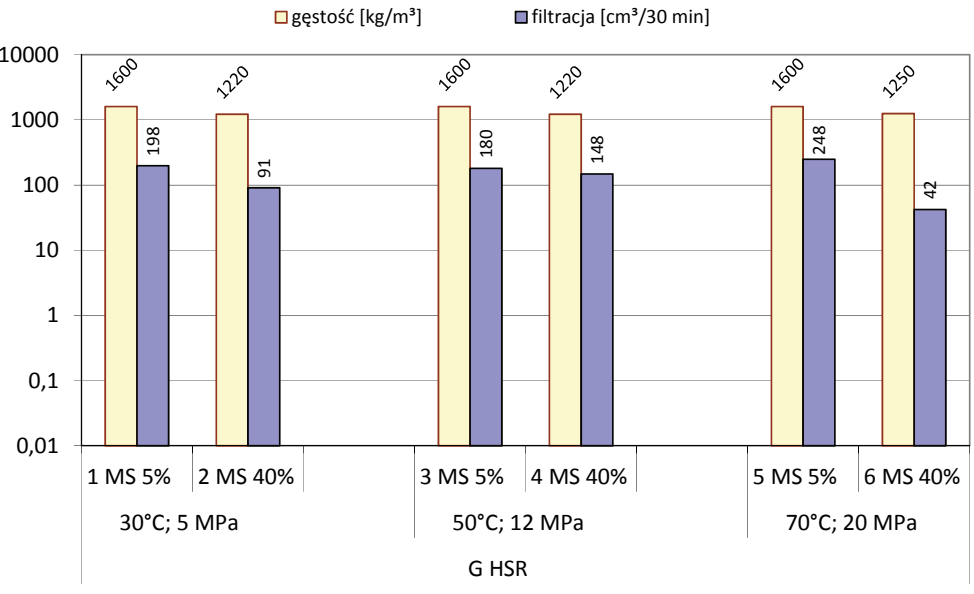

Numer, rodzaj zaczynu; warunki hydratacji; rodzaj spoiwa

Rys. 6. Wpływ dodatku mikrosfery na gęstość i filtrację zaczynu

Fig. 6. The effect of microsphere addition on slurry density and filtration 
Na podstawie uzyskanych wyników badań czasu gęstnienia zaczynów stwierdzono, że receptury zawierające $40 \%$ mikrosfer glinokrzemianowych charakteryzują się nieznacznie dłuższym czasem gęstnienia podczas badań w konsystometrze HTHP². Wzrost czasu początku gęstnienia $\left(30 \mathrm{Bc}^{3}\right)$ zawierał się w zakresie od 4 minut dla receptury przeznaczonej do warunków o temperaturze $30^{\circ} \mathrm{C}$ i ciśnieniu $5 \mathrm{MPa}$ do 26 minut dla receptury do warunków o temperaturze $70^{\circ} \mathrm{C}$ i ciśnieniu $20 \mathrm{MPa}$. Natomiast wzrost wartości czasu końca wiązania przypadający na wartość (100 Bc) wynosił od 15 minut (zaczyn dla temperatury $50^{\circ} \mathrm{C}$ i ciśnienia $12 \mathrm{MPa}$ ) do 23 minut dla zaczynu przeznaczonego do uszczelniania otworów w warunkach temperatury $30^{\circ} \mathrm{C}$ i ciśnienia $5 \mathrm{MPa}$. Dłuższych wartości czasu gęstnienia zaczynu nie można thumaczyć wzrostem ilości mikrosfer, lecz może być to spowodowane większą ilością cieczy zarobowej, na którą składa się zarówno wyższy współczynnik wodno-cementowy niż w recepturach kontrolnych, jak również dodatkowa objętość płynu, którą stanowi 10\%-owa objętość lateksu. Szczegółowe wartości czasu gęstnienia zestawiono na rysunku 7.

Przechodząc do kluczowych z punktu widzenia niniejszej publikacji właściwości, którymi są parametry reologiczne zaczynu, porównanie uzyskanych wartości zestawiono w tabeli 2. Na rysunku 8 zestawiono uzyskane wyniki w celu lepszego uwidocznienia zachodzących zmian wskutek zastosowania zwiększonej ilości dodatku mikrosfer. Zaobserwowano niewielki trend wzrostu lepkości opisywanej modelem Cassona w zaczynie przeznaczonym do uszczelniania kolumn rur w warunkach temperatury $30^{\circ} \mathrm{C}$ i ciśnienia $5 \mathrm{MPa}$. Mocniejszy wzrost wartości $\mathrm{z} 0,04 \mathrm{~Pa} \cdot \mathrm{s}$ do $0,08 \mathrm{~Pa} \cdot \mathrm{s}$ zaobserwowano w zaczynie dla warunków otworowych o temperaturze $50^{\circ} \mathrm{C}$ i ciśnieniu $12 \mathrm{MPa}$. Powyższe może skutkować nawet trzykrotnym wzrostem oporów przepływu zaczynu podczas tłoczenia, co wynika z rysunku 2 . Większa niż w poprzednich zaczynach różnica w uzyskanych wartościach lepkości pomiędzy zaczynem $\mathrm{nr} 3$ a zaczynem z mikrosferą oznaczonym nr 4, może być spowodowana faktem, iż w recepturze kontrolnej nr 3 zastosowano $0,2 \%$ upłynniacza, natomiast w poprzednim zaczynie kontrolnym oznaczonym $\mathrm{nr} 1$ upłynniacza było $0,1 \%$. Z kolei w zaczynach przeznaczonych

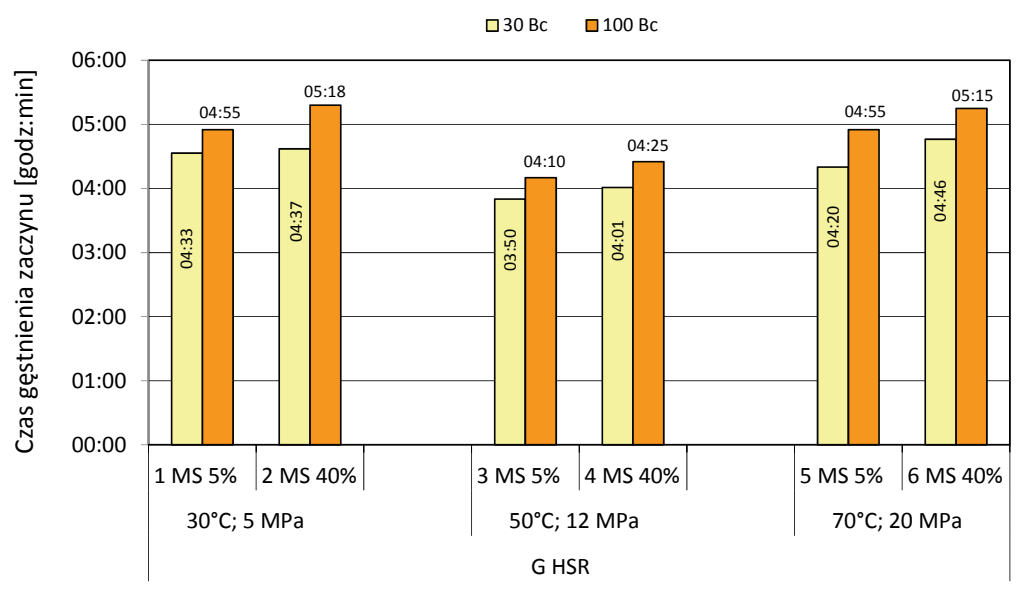

Numer, rodzaj zaczynu, warunki hydratacji; rodzaj spoiwa

Czas dojścia do temperatury: $30^{\circ} \mathrm{C}=10 \mathrm{~min} ; 70^{\circ} \mathrm{C}=40 \mathrm{~min} ; 50^{\circ} \mathrm{C}=25 \mathrm{~min}$

Rys. 7. Wpływ dodatku mikrosfer na zmianę czasu gęstnienia zaczynu cementowego

Fig. 7. The effect of microspheres addition on the change in cement slurry thickening time

do uszczelniania kolumn rur w warunkach temperatury $70^{\circ} \mathrm{C}$ i ciśnienia $20 \mathrm{MPa}$ wartość lepkości Cassona nie uległa zmianie (rys. 8). Widoczny jest również niewielki trend wzrostowy wartości współczynnika konsystencji opisywanej modelem Hershela-Bulkleya. Analizując dane zestawione w tabeli 2 oraz na rysunku 8 zaobserwowano, że najmocniejszy wzrost współczynnika konsystencji miał miejsce w recepturze dla

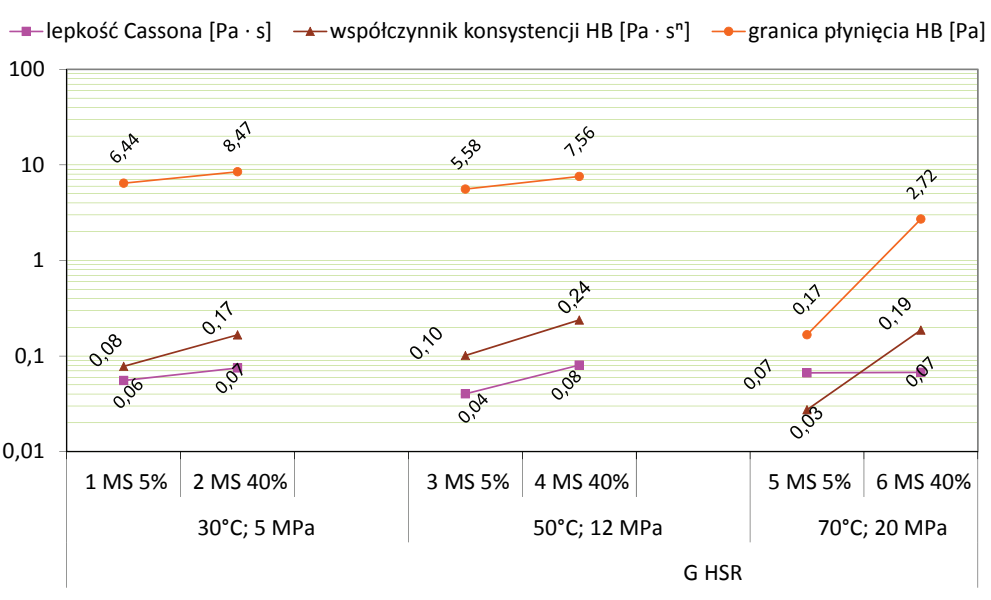

Numer, rodzaj zaczynu; warunki hydratacji; rodzaj spoiwa

Rys. 8. Zmiana wybranych parametrów reologicznych zaczynów cementowych pod wpływem wzrastającej ilości mikrosfery

Fig. 8. Change of selected rheological parameters of cement slurries under the influence of increasing amount of microsphere
${ }^{2}$ HTHT (ang. high temperature, high pressure) - badania prowadzone w warunkach podwyższonej temperatury i ciśnienia.

${ }^{3} \mathrm{Bc}$ - jednostka Beardena [-] miara konsystencji zaczynu podczas badania czasu gęstnienia w konsystometrze. warunków o temperaturze $70^{\circ} \mathrm{C}$ i ciśnieniu $20 \mathrm{MPa}$. Takie zachowanie może być wynikiem zastosowania mniejszej ilości bentonitu w zaczynie kontrolnym $\mathrm{nr} 5$ oraz dodatkową porcją środka opóźniającego wiązanie, który również powoduje dyspergowanie zaczynu. $\mathrm{Z}$ kolei w zaczynie nr $6 \mathrm{z}$ dodatkiem 
Tabela 2. Zestawienie wartości parametrów reologicznych zaczynów cementowych

Table 2. List of rheological parameters of cement slurries

\begin{tabular}{|c|c|c|c|c|c|c|c|}
\hline \multirow{2}{*}{$\begin{array}{l}\text { Model } \\
\text { reologiczny }\end{array}$} & \multirow[b]{2}{*}{ Parametry reologiczne } & \multicolumn{6}{|c|}{ Numer zaczynu } \\
\hline & & $\begin{array}{c}1 \\
(\text { MS 5) }\end{array}$ & $\begin{array}{c}2 \\
(M S 40)\end{array}$ & $\begin{array}{c}3 \\
\text { (MS 5) }\end{array}$ & $\begin{array}{c}4 \\
\text { (MS 40) }\end{array}$ & $\begin{array}{c}5 \\
\text { (MS 5) }\end{array}$ & $\begin{array}{c}6 \\
(\mathrm{MS} 40)\end{array}$ \\
\hline \multirow{2}{*}{ Model Newtona } & Lepkość dynamiczna $[\mathrm{Pa} \cdot \mathrm{s}]$ & 0,0918 & 0,1253 & 0,0727 & 0,1231 & 0,0674 & 0,0924 \\
\hline & Współczynnik korelacji [-] & 0,9831 & 0,9769 & 0,9700 & 0,9893 & 0,9970 & 0,9887 \\
\hline \multirow{3}{*}{ Model Binghama } & Lepkość plastyczna $[\mathrm{Pa} \cdot \mathrm{s}]$ & 0,0822 & 0,1105 & 0,0630 & 0,1132 & 0,0695 & 0,0848 \\
\hline & Granica płynięcia $[\mathrm{Pa}]$ & 6,3138 & 9,8113 & 6,4745 & 6,5677 & 1,4125 & 5,0335 \\
\hline & Współczynnik korelacji [-] & 0,9993 & 0,9986 & 0,9993 & 0,9986 & 0,9981 & 0,9984 \\
\hline \multirow{3}{*}{$\begin{array}{l}\text { Model Ostwalda } \\
\text { de Waele }\end{array}$} & Współczynnik konsystencji $\left[\mathrm{Pa} \cdot \mathrm{s}^{\mathrm{n}}\right]$ & 2,0515 & 2,7969 & 2,1052 & 2,1746 & 0,0983 & 1,0035 \\
\hline & Wykładnik potęgowy [-] & 0,4924 & 0,4984 & 0,4486 & 0,5324 & 0,9112 & 0,6155 \\
\hline & Współczynnik korelacji [-] & 0,9194 & 0,9381 & 0,9195 & 0,9204 & 0,9622 & 0,9682 \\
\hline \multirow{3}{*}{ Model Cassona } & Lepkość Cassona $[\mathrm{Pa} \cdot \mathrm{s}]$ & 0,0554 & 0,0749 & 0,0402 & 0,0803 & 0,0666 & 0,0675 \\
\hline & Granica płynięcia $[\mathrm{Pa}]$ & 2,8679 & 4,2662 & 2,7737 & 3,1110 & 0,0169 & 1,4877 \\
\hline & Współczynnik korelacji [-] & 0,9952 & 0,9974 & 0,9971 & 0,9942 & 0,9946 & 0,9998 \\
\hline \multirow{4}{*}{$\begin{array}{l}\text { Model Hersche- } \\
\text { la-Bulkleya }\end{array}$} & Granica płynięcia $[\mathrm{Pa}]$ & 6,4387 & 8,4664 & 5,5778 & 7,5613 & 0,1668 & 2,7154 \\
\hline & Współczynnik konsystencji $\left[\mathrm{Pa} \cdot \mathrm{s}^{\mathrm{n}}\right]$ & 0,0779 & 0,1665 & 0,1012 & 0,2383 & 0,0274 & 0,1866 \\
\hline & Wykładnik potęgowy [-] & 1,0079 & 0,9411 & 0,9319 & 1,0476 & 1,1343 & 0,8869 \\
\hline & Współczynnik korelacji [-] & 0,9994 & 0,9990 & 0,9998 & 0,9987 & 0,9997 & 0,9997 \\
\hline
\end{tabular}

mikrosfery większa ilość bentonitu i brak opóźniacza wiązania przyczynił się do wzrostu wartości współczynnika konsystencji.

Bardzo istotnym parametrem reologicznym w recepturach zaczynów cementowych jest także granica płynięcia, której wartość wzrasta wraz ze wzrostem udziału dodatku mikrosfer. Przy czym najmocniejszy trend wzrostowy granicy płynięcia opisywanej modelem Hershela-Bulkleya można

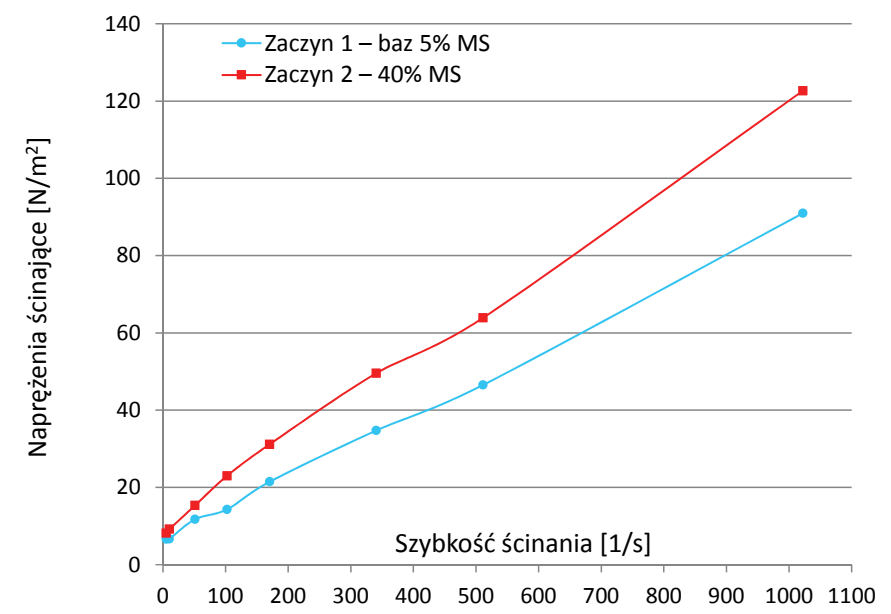

Rys. 9. Zmiana przebiegu krzywych płynięcia zaczynów cementowych pod wpływem wzrastającej ilości mikrosfery glinokrzemianowej (zaczyn dla warunków otworowych o temperaturze $30^{\circ} \mathrm{C}$ i ciśnieniu $5 \mathrm{MPa}$ )

Fig. 9. Change in the flow curves of cement slurries due to the increasing amount of aluminosilicate microsphere (slurry for borehole conditions at $30^{\circ} \mathrm{C}$ and a pressure of $5 \mathrm{MPa}$ ) zaobserwować (analogicznie jak podczas interpretacji współczynnika konsystencji) w zaczynie dla warunków o temperaturze $70^{\circ} \mathrm{C}$ i ciśnieniu $20 \mathrm{MPa}$.

Dodatkowo w celu lepszego zobrazowania wpływu dodatku mikrosfer glinokrzemianowych na parametry reologiczne świeżego zaczynu cementowego (na rysunkach od 9 do 11) przedstawiono zmianę przebiegu wartości krzywych płynięcia

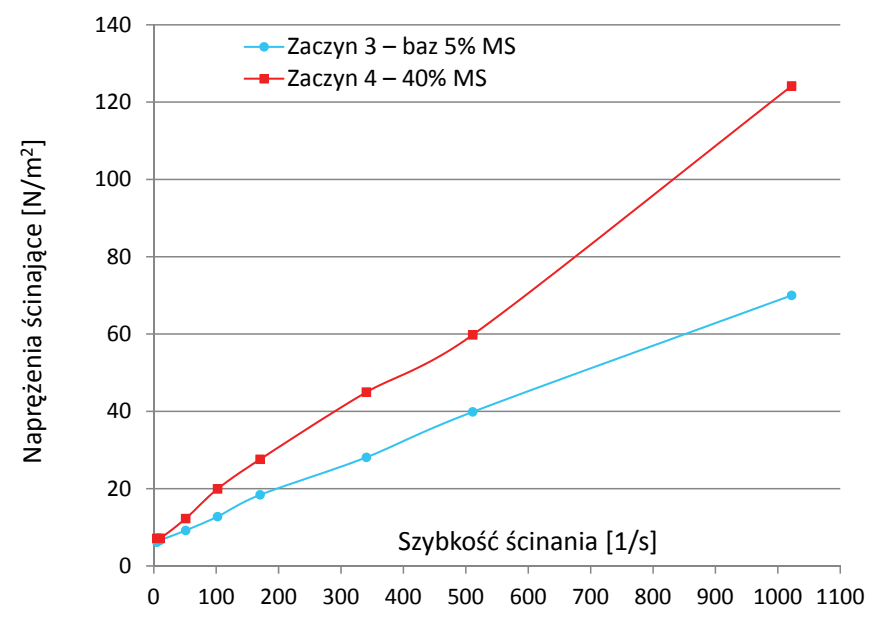

Rys. 10. Zmiana przebiegu krzywych płynięcia zaczynów cementowych pod wpływem wzrastającej ilości mikrosfery glinokrzemianowej (zaczyn dla warunków otworowych o temperaturze $50^{\circ} \mathrm{C}$ i ciśnieniu $18 \mathrm{MPa}$ )

Fig. 10. Change in the flow curves of cement slurries due to the increasing amount of aluminosilicate microsphere (slurry for borehole conditions at $50^{\circ} \mathrm{C}$ and a pressure of $18 \mathrm{MPa}$ ) 


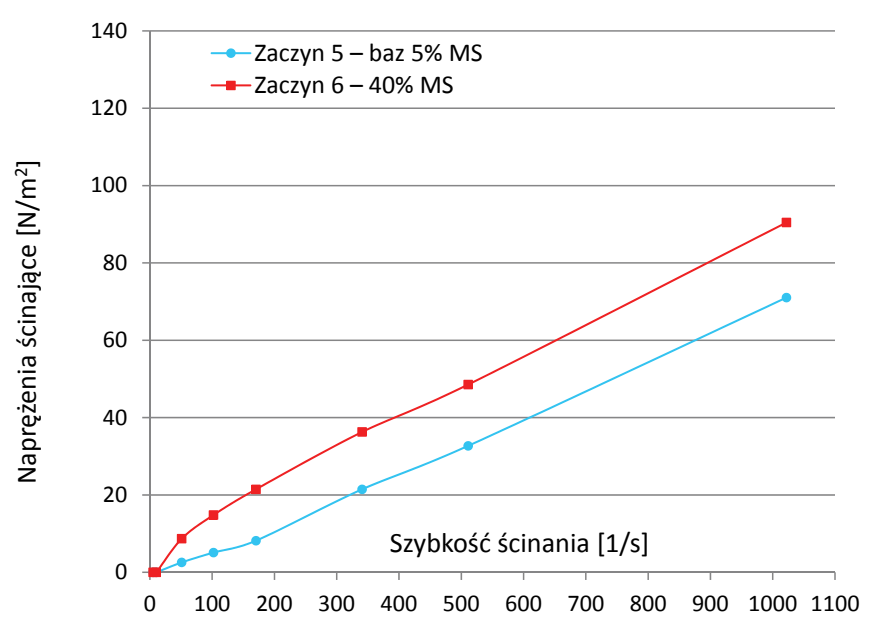

Rys. 11. Zmiana przebiegu krzywych płynięcia zaczynów cementowych pod wpływem wzrastającej ilości mikrosfery glinokrzemianowej (zaczyn dla warunków otworowych o temperaturze $70^{\circ} \mathrm{C}$ i ciśnieniu $25 \mathrm{MPa}$ )

Fig. 11. Change in the flow curves of cement slurries due to the increasing amount of aluminosilicate microsphere (slurry for borehole conditions at $70^{\circ} \mathrm{C}$ and a pressure of $25 \mathrm{MPa}$ )

dla zaczynu kontrolnego i zaczynu z dodatkiem $40 \%$ mikrosfer. Dla wszystkich analizowanych receptur widoczny jest wzrost wartości naprężeń ścinających w przypadku receptur zawierających zwiększoną (40\%-ową) ilość mikrosfer glinokrzemianowych. Przy czym wzrost ten jest proporcjonalny do wzrostu szybkości ścinania dla odpowiadającego danej recepturze zaczynu bazowego oznaczonego numerem 2 oraz 4 (rys. 9 i 10). Z kolei w przypadku zaczynu 6 przebieg krzywej płynięcia jest niemal równoległy do przebiegu krzywej płynięcia zaczynu bazowego oznaczonego numerem 5 (rys. 11), co świadczy o niemal niezmiennych wartościach lepkości Cassona (rys. 8).

Analizując uzyskane wyniki badań stwierdzono, że dodatek mikrosfery glinokrzemianowej powoduje wzrost parametrów reologicznych, co nie jest bez znaczenia podczas projektowania receptur zaczynów o obniżonej gęstości. Parametry te można zmodyfikować za pomocą środków dyspergujących (upłynniaczy, plastyfikatorów, superplastyfikatorów) czy nawet poprzez zastosowanie dodatkowej porcji wody zarobowej. Jednakże takie działanie może być niekorzystne ze względu na pogorszenie stabilności sedymentacyjnej objawiające się nadmiernym frakcjonowaniem wypełniacza lekkiego, jakim jest dodatek mikrosfer glinokrzemianowych.

\section{Wnioski}

Na podstawie zrealizowanych prac badawczych określających zmiany zachodzące $\mathrm{w}$ wartościach parametrów reologicznych zaczynów lateksowych pod wpływem dodatku mikrosfery sformułowano następujące wnioski końcowe:
- Obecność mikrosfer glinokrzemianowych w recepturze zaczynu cementowego przyczynia się do wzrostu wartości lepkości plastycznej zaczynu opisywanej za pomocą modelu Cassona. Zaobserwowano wzrost lepkości Cassona o $0,04 \mathrm{~Pa} \cdot \mathrm{s}$ w stosunku do zaczynu bazowego po zastosowaniu 40\% mikrosfer glinokrzemianowych. Takie działania dodatkowej porcji mikrosfer glinokrzemianowych może się przyczynić do 3-krotnego lub większego wzrostu oporów przepływu podczas tłocznia zaczynu cementowego. Wynikiem powyższego może być zagrożenie szczelinowaniem przede wszystkim warstw słabozwięzłych i sypkich, do których uszczelniania stosowane są właśnie zaczyny o obniżonej gęstości.

- Dodatek $40 \%$ mikrosfer glinokrzemianowych powoduje również wzrost wartości współczynnika konsystencji $\mathrm{HB}$ w zakresie od $0,09 \mathrm{~Pa} \cdot \mathrm{s}^{\mathrm{n}}$ (zaczyn dla $30^{\circ} \mathrm{C}$ ) do $0,16 \mathrm{~Pa} \cdot \mathrm{s}^{\mathrm{n}}$ (zaczyn dla $70^{\circ} \mathrm{C}$ ). Największy wzrost zaobserwowano w recepturze zaczynu dla warunków temperatury $70^{\circ} \mathrm{C}$ i ciśnienia $20 \mathrm{MPa}$, jednak w tym przypadku na wzrost wartości współczynnika konsystencji mogły wpływać również zróżnicowania w składzie zaczynu, które były konieczne w celu dostosowania danej receptury do powyższych warunków geologiczno technicznych (temperatura $70^{\circ} \mathrm{C}$, ciśnienie $20 \mathrm{MPa}$ ).

- Wartości granicy płynięcia opisywanej modelem HershelaBulkleya również ulegały wzrostowi wraz ze wzrastającą ilością dodatku mikrosfer glinokrzemianowych w zaczynie cementowym. Zaobserwowano podobny trend jak podczas analizy wartości współczynnika konsystencji, objawiający się tym, że największe różnice pomiędzy zaczynem kontrolnym a zaczynem $\mathrm{z}$ dodatkiem $40 \%$ mikrosfer glinokrzemianowych występowały w próbkach zaczynów sporządzonych dla warunków o temperaturze $70^{\circ} \mathrm{C}$ i ciśnieniu $20 \mathrm{MPa}$. Może to mieć również związek ze zróżnicowaniem w składzie zaczynu.

- Potwierdzeniem znacznego wpływu mikrosfer glinokrzemianowych na parametry reologiczne opracowywanych zaczynów są rozbieżności w przebiegu krzywych płynięcia, gdzie przebieg wartości naprężeń ścinających uzyskuje wyższe wartości w zaczynie zawierającym $40 \%$ mikrosfer glinokrzemianowych niż w przypadku zaczynów zawierających 5\% tego dodatku.

Może się wydawać oczywiste, że dodatek znacznych ilości mikrosfer będzie powodował wzrost konsystencji zaczynu cementowego, jednakże podczas wprowadzania dodatkowych porcji wypełniacza lekkiego stosuje się również środki dyspergujące w celu uzyskania wymaganych wartości parametrów reologicznych. Taki schemat działania zastosowany został również w powyższych pracach badawczych, lecz mimo tego dodatek mikrosfer glinokrzemianowych spowodował zmianę 
parametrów reologicznych nowoopracowanych receptur zaczynów lekkich. Należy również wspomnieć, iż projektowanie receptur zaczynów i zabiegu cementowania jest weryfikowane przy użyciu specjalistycznych programów np.: CEMCADE, OPTICEM, które są stosowane przez Serwis Cementacyjny EXALO. Programy te pozwalają na sprawdzenie i weryfikację zaczynu o zadanych parametrach reologicznych pod kątem zastosowania w konkretnych warunkach otworowych (temperatura, ciśnienie porowe i ciśnienie szczelinowania).

Artykuł powstał na podstawie pracy badawczej pt.: Analiza możliwości doszczelnienia mikrostruktury płaszcza cementowego za pomoca nowych domieszek drobnoziarnistych - praca INiG - PIB na zlecenie MNiSW; nr zlecenia: 0044/KW/2019, nr archiwalny: DK-4100/0034/2019.

\section{Literatura}

Bayu S., Muhammed T.F., Roby T., 2010. Effect of lignosulfonate and temperature on compressive strength of cement. Proceedings of World Geothermal Congress, Bali, Indonesia: 1-3.

Bensted J., 2004. Cementy wiertnicze. Cz. 2. Stosowanie cementów wiertniczych do cementowania odwiertów. Cement Wapno Beton, 2: 61-72.

Falode O.A., Salam K.K., Arinkoola A.O., Ajagbe B.M., 2013. Prediction of compressive strength of oil field class G cement slurry using factorial design. Journal of Petroleum Exploration and Production Technology, 3(4): 297-302.

Herianto A., Fathaddin M.T., 2005. Effects of additives and conditioning time on comprehensive and shear bond strengths of geothermal well cement. Proceedings of World Geothermal Congress, Antalya, Turkey: 1-7.

Jordan A., Pernites R., Albrighton L., 2018. Low-density, lightweight cement tested as alternative to reduce lost circulation, achieve desired top of cement in long horizontal wells. Drillingcontactor: 62-64.

Kremieniewski M., 2017a. Poprawa stabilności sedymentacyjnej zaczynu cementowego. Nafta-Gaz, 4: 242-249. DOI: 10.18668/ NG.2017.04.04.

Kremieniewski M., 2017b. Wpływ perlitu pylistego na własności technologiczne zaczynu cementowego. Nafta-Gaz. 12: 943-952. DOI: 10.18668/NG.2017.12.05.

Kremieniewski M., 2018a. Poprawa wczesnej wytrzymałości mechanicznej płaszcza cementowego powstałego z zaczynu lekkiego. Nafta-Gaz, 8: 599-605. DOI: 10.18668/NG.2018.08.06.

Kremieniewski M., 2018b. Wpływ środków regulujących czas wiązania na parametry reologiczne zaczynu cementowego. Nafta-Gaz, 11: 828-838. DOI: 10.18668/NG.2018.11.07.

Kremieniewski M., 2019a. O konieczności prowadzenia serwisowych badań parametrów technologicznych zaczynów uszczelniających. Nafta-Gaz, 1: 48-55. DOI: 10.18668/NG.2019.01.07.

Kremieniewski M., 2019b. Receptury zaczynów do uszczelniania kolumn rur posadowionych w otworach wierconych w skałach chłonnych. Nafta-Gaz, 8: 451-457. DOI: 10.18668/NG.2019.08.01.

Kremieniewski M., 2019c. Rola plastyfikatora w projektowaniu zaczynu lekkiego o podwyższonej stabilności sedymentacyjnej. Nafta-Gaz, 9: 571-578. DOI: 10.18668/NG.2019.09.06.
Kremieniewski M., Rzepka M. 2016. Przyczyny i skutki przepływu gazu w zacementowanej przestrzeni pierścieniowej otworu wiertniczego oraz metody zapobiegania temu zjawisku. Nafta-Gaz, 9: 722-728. DOI: 10.18668/NG.2016.09.06.

Kremieniewski M., Stryczek S., 2019. Zastosowanie cementu wysokoglinowego do sporządzania zaczynów uszczelniających w technologiach wiertniczych. Cement Wapno Beton, 3: 215-226.

Kremieniewski M., Stryczek S., Wiśniowski R., Rzepka M., Gonet A., 2017. Wpływ dodatku montmorylonitu/bentonitu/ na parametry świeżego i stwardniałego zaczynu cementowego. AGH Drilling, Oil, Gas, 34: 323-334.

Kudowski W., 2010. Chemia cementu i betonu. Wydawnictwo Naukowe PWN, Warszawa: 1-700.

Nelson E.B. et al., 1990. Well Cementing, Schlumberger Educational Service, Houston, Teksas, USA.

Półchłopek T. (kier. zespołu), 1993. Zaczyny cementowe do cementowania otworów kierunkowych i poziomych oraz technologia ich zatłaczania. Praca INiG, Archiwum Instytutu Nafty $i$ Gazu - Państwowego Instytutu Badawczego, Kraków.

Peng Ya, Jacobsen S., 2013. Influence of water/cement ratio, admixtures and filler on sedimentation and bleeding of cement paste. Cement and Concrete Research, 54: 133-142. DOI: 10.1016/j. cemconres.2013.09.003.

Raczkowski J., Stryczek S., Fugiel K., Kraj Ł., Wilk S., 1978. Zaczyny do uszczelniania w otworach wiertniczych. Skrypty uczelniane, Akademia Górniczo-Hutnicza: 1-311.

Rzepka M., Kremieniewski M., Dębińska E., 2012. Zaczyny cementowe przeznaczone do uszczelniania eksploatacyjnych kolumn rur okładzinowych na Niżu Polskim. Nafta-Gaz, 8: 512-522.

Rzepka M., Stryczek S., 2008. Laboratoryjne metody określania parametrów technologicznych świeżych zaczynów uszczelniających przed zabiegiem związanym z procesem uszczelniania kolumn rur okładzinowych w otworach wiertniczych. Wiertnictwo, Nafta-Gaz, 25(2): 625-636.

Stryczek S., Gonet A., Wiśniowski R., 2005. Wpływ wybranego dodatku mineralnego na własności technologiczne zaczynów cementowych. Wiertnictwo, Nafta, Gaz, 22(1): 333-341.

Stryczek S., Wiśniowski R., Gonet A., Ferens W., 2009. Parametry reologiczne świeżych zaczynów uszczelniających w zależności od czasu ich sporządzania. Wiertnictwo, Nafta, Gaz, 26(1-2): 369-382.

Stryczek S., Wiśniowski R., Gonet A., Złotkowski A., 2014. The influence of time of rheological parameters of fresh cement slurries. AGH Drilling, Oil, Gas, 31: 123-133 DOI: 10.7494/ drill.2014.31.1.123.

Wiśniowski R., Stryczek S., Skrzypaszek K., 2007. Kierunki rozwoju badań nad reologią płynów wiertniczych. Wiertnictwo, Nafta, Gaz, 24: 595-607.

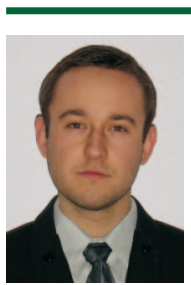

Dr inż. Marcin KREMIENIEWSKI

Adiunkt w Zakładzie Technologii Wiercenia Instytut Nafty i Gazu - Państwowy Instytut Badawczy ul. Lubicz $25 \mathrm{~A}$

31-503 Kraków

E-mail: marcin.kremieniewski@inig.pl 